Canadian

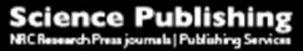

Botany

Botanique

\title{
Classification and environmental correlates of tidal wetland vegetation in Nova Scotia, Canada.
}

\begin{tabular}{|r|l|}
\hline Journal: & Botany \\
\hline Manuscript ID & cjb-2015-0066.R2 \\
\hline Danuscript Type: & Article \\
\hline Complete List of Authors: & $\begin{array}{l}\text { Porter, Caitlin; Saint Mary's University, Biology } \\
\text { Lundholm, Jeremy; Saint Mary's University, Biology } \\
\text { Bowron, Tony; CBWES, } \\
\text { Lemieux, Ben; CBWES, } \\
\text { van Proosdij, Danika; Saint Mary's University, Geography } \\
\text { Neatt, Nancy; CBWES, } \\
\text { Graham, Jennie; CBWES, }\end{array}$ \\
\hline Keyword: & Plant communities, Salinity, Tidal wetland, Salt marsh , <i>S Spartina </i> \\
\hline & \multicolumn{2}{l}{} \\
\hline
\end{tabular}

\section{SCHOLARONE ${ }^{m}$ \\ Manuscripts}


1 Classification and environmental correlates of tidal wetland vegetation in Nova Scotia,

2 Canada.

4 Caitlin Porter $^{1}$, Jeremy Lundholm ${ }^{1}$ Tony Bowron $^{2}$, Ben Lemieux ${ }^{2}$, Danika van Proosdij ${ }^{3}$, Nancy

5 Neatt $^{2}$, and Jennie Graham ${ }^{2}$

6

7

8 1. Porter, C. (caitlinjmporter@gmail.com) \& Lundholm, J. (jlundholm@smu.ca): Department of Biology,

9 Saint Mary’s University, 923 Robie St., Halifax, NS B3H 3C32. Bowron, T. (Tony.Bowron@gmail.com),

10 Lemieux, B. (ben.d.lemieux@gmail.com), Neatt, N. (nancy.neatt@gmail.com) \& Graham, J.

11 (jen.m.graham@gmail.com): CB Wetlands and Environmental Specialists (CBWES Inc.), 331 Newbury

12 Road, Hammonds Plains, Halifax, NS B4B 0C6. ${ }^{3 .}$ van Proosdij, D. (dvanproo@smu.ca): Department of

13 Geography and Environmental Studies, Saint Mary's University, 923 Robie St., Halifax, NS B3H 3C3

14

15 Corresponding author: Caitlin Porter. Address: Department of Biology, Saint Mary’s University, 923

16 Robie St., Halifax, NS B3H 3C3. Phone: (902) 719-4815. Email: caitlinjmporter@gmail.com,

17 
18 Abstract: We numerically classified tidal wetland vegetation and determined the relationships

19 between variation in plant species composition and environmental factors.

20 Sampling was conducted at eight sites along a range of tidal magnitudes ( $<2$ to $>14 \mathrm{~m}$ ). Cluster

21 analysis revealed seven distinct salt or brackish marsh plant associations, usually dominated by a

22 single graminoid species. Redundancy analysis showed continuous variation among community

23 units and identified inundation time, elevation, soil salinity and organic matter content as key

24 correlates of plant community patterns. Associations detected were similar to those found in New

25 Brunswick Bay of Fundy and Northumberland Strait wetlands, and to those farther south in

26 northern New England, but two new brackish associations were also identified within this study

27 (Juncus balticus-Festuca rubra and Spartina pectinata). Although elevation is understood to

28 drive vegetation types in salt marshes in the region, here we show that salinity can differentiate

29 vegetation types at the same elevation. These data provide a quantitative baseline and allow for

30 better predictions of tidal wetland ecological restoration trajectories in Nova Scotia.

31 Key words: Plant communities, Tidal wetland, Salt marsh, Salinity, Inundation, Spartina 


\section{Introduction}

34 Tidal wetlands comprise some of the most fertile and valuable coastal habitats globally and are important

35 features of the north-eastern Atlantic coastline of North America. Tidal wetlands provide many ecosystem

36 services including buffering of coastal zones from storm damage, and provision of habitat for ecologically

37 significant and commercially important species (Fernald 1920, McAloney 1981, Roberts and Robertson

38 1986, Hicklin 1987, Fielding 2001, Craft et al. 2009). Tidal wetlands are regularly inundated and

39 characterized by a salinity gradient (Ewanchuk and Bertness 2004). Within eastern North America, the

40 salinity gradient is represented by freshwater marshes at higher elevations and salt marshes at relatively

41 lower elevations. These tidal wetlands are dominated by highly productive graminoids, mainly grasses

42 (Poaceae), sedges (Cyperaceae) and rushes (Juncaceae) (Zoltai and Vitt 1995, Warner and Rubec 1997).

43 Past works indicate that the zonation is maintained by biotic interactions between plant species, resulting

44 in the dominance of competitive species in more benign conditions, and stress-tolerant subordinate

45 species in areas subjected to increased inundation and salinity (Bertness and Ellison 1987, Bertness

46 1991a, Pennings and Callaway 1992, Pennings et al. 2005). 
47 Development pressures have historically resulted in losses of European (e.g., Tonis et al. 2002) and

48 North American (e.g., Neckles et al. 2002) tidal wetlands. In the three Maritime Provinces of Canada

49 (Nova Scotia, New Brunswick, and Prince Edward Island), approximately $70 \%$ of the historical area of

50 salt marsh has been lost, primarily due to dyking (Hanson and Calkins 1996). Nova Scotia contains over

$5150 \%$ of remaining salt marsh in the region (Bowron et al. 2012) divided among three distinct coastlines:

52 the Atlantic Coast, the Bay of Fundy and the Northumberland Strait/Gulf of St. Lawrence.

53 There is a need for more robust quantitative classification and description of ecological conditions of

54 tidal wetlands since restoration projects have become more prevalent in Maritime Canada over the past 30

55 years, and are increasingly important because climate change-associated sea level rise pressures marsh

56 ecosystems (Olsen et al. 2005, Singh et al. 2007). Awareness of the loss of fish habitat and the threats to

57 shoreline stability posed by relative sea level rise now prompt efforts to restore the ecological functioning

58 of tidal wetlands (Bowron et al. 2011).

59 Research quantifying environmental factors and statistical analysis of vegetation-environment

60 relationships of tidal wetlands in eastern Canada is limited. Previous accounts of salt marsh community

61 composition and environmental drivers for tidal wetlands in Nova Scotian are largely either qualitative or 
62 assess only a limited number of sites (Ganong 1903, Chapman 1937, 1974, Pielou and Routledge 1976,

63 Thannheiser 1984, Roberts and Robertson 1986). Nova Scotian tidal wetlands have many of the same

64 communities recognized further south in New England (Bertness and Ellison 1987, Jacobson and

65 Jacobson 1989) including a low marsh zone dominated by Spartina alterniflora Loisel. and a mid- to high

66 marsh zone dominated by Spartina patens (Aiton) Muhl.. Despite broad similarities between tidal

67 vegetation in Nova Scotia and the other Maritime Provinces (e.g., Chmura et al. 1997, Olsen et al. 2005),

68 and the well-studied tidal vegetation in New England, it is also known that species with a more northerly

69 distribution can be common in the plant communities in the Bay of Fundy (Jacobson and Jacobson 1989,

70 Chmura et al. 1997) and very little of the literature covers the brackish areas higher in the tidal frame

71 which are quite common in many Nova Scotia marshes. The goals of this study were to classify tidal

72 wetland vegetation, including brackish communities, in Nova Scotia using multivariate statistical and

73 ordination methods, and to determine the environmental drivers of plant community composition.

\section{Materials and Methods}

75 Study region 
76 Nova Scotia's climate is broadly categorized within the humid continental type, warm summer subtype

77 according to the Koppen Climate Classification (Peel et al. 2007)(Appendix A6). Eight sites were selected

78 to represent three distinctive coastal areas of Nova Scotia (Table 1; Fig. 1) (Bowron et al. 2012): the Bay

79 of Fundy Region, the Atlantic Coast, and the Carboniferous Lowlands of the Gulf of St.

80 Lawrence/Northumberland Strait Region. The sites (Table 1) serve as reference sites for ecological

81 restoration activities in the region (e.g., van Proosdij et al. 2010); six from the Bay of Fundy, one Atlantic

82 coast and one from the Northumberland Strait (Appendix A6). The Bay of Fundy region has the majority

83 of tidal marsh habitat in the province and currently hosts the most established salt marsh ecological

84 restoration projects in the region (van Proosdij et al. 2010, Bowron et al. 2011, 2012).

85 Vegetation was systematically sampled throughout July and August (peak biomass) along transects

86 oriented perpendicular to the primary watercourse. Transect plot sampling was used rather than

87 subjectively placed releve plots since this method may be particularly important for detecting fine-scale

88 patterns in marshes by avoiding assumptions frequently made about stand homogeneity (Zedler 1999).

89 Transects were oriented from a benchmark at the upland edge of each marsh, delineated by the distinct

90 hydrological, vegetation and elevation boundary associated with wetlands. For most of the sites, this 
91 boundary corresponded with the discrete toe of a steep slope. The upland edge of marshes was included in

92 the sampling design mainly to support ongoing long-term monitoring of these sites, but also to maintain

93 sampling consistency in the grid pattern between sites and to capture a wide gradient in elevation and

94 zonal vegetation. Transects spanned the breadth of each marsh from the upland edge to the primary

95 watercourse. The interval distances between transects and between samples along each transect were

96 consistent within sites but varied between sites dependent upon site size.

97 Long-term data from vegetation plots over the last 10 years at these sites indicate vegetation was

98 stable over the course of monitoring save for variation in the size and location of small unvegetated salt

99 water pannes or natural site disturbances including ice scarification and creek bank erosion. The salinity

100 and sediment sampling methodology was updated in 2009; therefore the analysis used 2010 vegetation,

101 salinity and sediment data for consistency, with the exception of Smith Gut at which all variables were

102 sampled in 2009.

103 Plant species composition and abundance were sampled from $1 \mathrm{~m}^{2}$ quadrats using the point-intercept

104 method (e.g., Roman et al. 2002). Each quadrat was divided into 25 grid squares $(20 \mathrm{~cm} \mathrm{x} 20 \mathrm{~cm})$ and

105 sampling was conducted at the intercept points using a wooden dowel (3mm diameter, $1 \mathrm{~m}$ length). 
106 Vegetation height was measured to the nearest $0.01 \mathrm{~m}$ for the most abundant species in each plot. The

107 number of pins contacting a species was used as a measure of abundance of that species within the plot;

108 species rooted in the plot but not contacting a pin were assigned a value of 0.05 . All plants were identified

109 to species level. Scientific nomenclature is provided according to the International Taxonomic

110 Information System database (ITIS 2015), but common names follow the Atlantic Canada Conservation

111 Data Centres database (ACCDC 2015).

112 Environmental variables

113 All sample plots were surveyed using a Trimble R8 GNSS RTK GPS surveying system which has a

114 reported accuracy of $9 \mathrm{~mm}$ horizontal and $15 \mathrm{~mm}$ vertical. In 2010, surveys were processed by a third

115 party and accuracy reports were not provided. However, accuracy reports for subsequent surveys in the

116 same region made with the same equipment had a horizontal precision of $12 \pm 13 \mathrm{~mm}$, vertical precision

117 of $19 \pm 19 \mathrm{~mm}$, and position (3D) dilution of precision of $1.51 \pm 0.51$. Elevations are reported relative to

118 the Canadian Geographic Vertical Datum of 1928 (CGVD28), which is referenced from Mean Water

119 Level (MWL) measurements made in 1928 at tide gauges across Canada. To incorporate tidal range into

120 analyses, hydroperiod was determined for each sample plot. Inundation frequency and mean inundation 
121 time for all study sites was determined using plot elevations and predicted tide heights. Predicted tidal

122 signal (5 minute interval) and high tide elevations were obtained for Canadian Hydrographic Service

123 (CHS) tide stations at Chezzetcook Inlet (CHS tide station \#43), Merigomish (CHS tide station \#1620),

124 and Hantsport (CHS tide station \#282) using Tides and Currents Pro v2.5. The data were then converted

125 from Chart Datum (CD) to CGVD28 using reference benchmarks provided by CHS to allow comparison

126 to surveyed plot elevations. Inundation frequency was calculated by determining the percentage of

127 predicted high tides within the year that exceed the plots elevation and result in tidal flooding. Mean

128 inundation time was calculated by using the tidal signal to determine the total amount of time each plot

129 was flooded and dividing by the number of high tide events that resulted in tidal inundation.

Interstitial pore water salinity was sampled three times in July, August and September, from a subset

131 of the vegetation sampling stations representative of tidal and elevation range of each marsh (Table 1).

132 Samples were collected at low tide when there was no precipitation. At each sampling location a shallow

$133(15 \mathrm{~cm})$ and a deep $(45 \mathrm{~cm})$ pore water sample was taken using a soil probe sipper constructed according

134 to the design specified in Roman et al. (2002), with larger diameter tubing (4 $\mathrm{mm})$ to accommodate the

135 minerogenic conditions experienced on marshes in the Minas Basin. The sample design is intended to 
136 capture variability in pore water samples observed seasonally and spatially, both within the rooting zone

137 and across the marsh platform. Pore water samples were stored until suspended particles settled, after

138 which a refractometer (nearest 2 ppt) reading was collected. Salinity data were averaged to provide a

139 single mean value per location for use in analyses.

140 Paired sediment cores were collected from a subset of vegetation plots using a stratified random

141 sampling procedure to ensure that different elevations were sampled (Table 1). Sample size varied

142 between sites depending on sampling design and intensity at any given site (Table 1). The first of the two

143 cores was collected by inserting a $30 \mathrm{ml}$ syringe ( $26 \mathrm{~mm}$ diameter; $53 \mathrm{~mm}$ depth) for bulk density and the

144 second collected by pressing a metal tube $(10.16 \mathrm{~cm}$ long and $3.81 \mathrm{~cm}$ diameter $)$ to level with sediment

145 surface and ensuring that the interior and exterior surface levels were equal. Bulk density $\left(\mathrm{g} / \mathrm{cm}^{3}\right)$ was

146 determined by drying and weighing a known volume of the sample. The second core was removed from

147 the ground using a knife and trowel to minimize compaction and individually capped, sealed in a plastic

148 bag, labelled and frozen. The top $2 \mathrm{~cm}$ of this core was removed, sectioned into two equally sized sub-

149 samples. One sub-sample was weighed and placed in a crucible for drying at $105{ }^{\circ} \mathrm{C}$ for 24 hrs to

150 determine water content. Once dried, each sample was weighed and placed in a muffle furnace for two 
151 hours at $550{ }^{\circ} \mathrm{C}$. These subsamples were then cooled in a desiccating jar and weighed again to calculate

152 loss on ignition (LOI) of organic material. Coarse organic material was removed using tweezers from the

153 second sub-sample destined for grain size analysis. Remaining organic fraction was removed by digestion

154 using $30 \%$ hydrogen peroxide in order to prevent fusing the fine fraction. The resultant mineral sediment

155 of the second sub-samples were then processed through a Coulter Laser Multisizer 3, merged using a

156 customized script in Matlab and analyzed using Gradistat (Blott and Pye 2001). Size classes were

157 determined using a modified Udden-Wentworth scale (Blott and Pye 2001).

158 Statistical analyses

159 To explore multivariate relationships in plant species composition, a Principal Components Analysis

160 (PCA) was conducted on Hellinger's transformed species abundance data to overcome limitations related

161 to linear assumptions (Legendre and Gallagher 2001). Though more traditional ordination techniques can

162 provide similar projections of species coordinates in multivariate space, PCA was best suited for these

163 analyses because of its high resolution (lack of distortion), solution (outcome of analyses) stability

164 (Legendre and Legendre 1998, Wildi 2010) and because it avoids the risk of uncontrolled alteration to the

165 similarity pattern inherent within detrending procedures (Legendre and Legendre 1998, Wildi 2010, 
166 Borcard et al. 2011). Axes with eigenvalues greater than one were considered significant and used for

167 interpretation.

168 Redundancy Analysis (RDA) was used to determine relationships between plant species composition

169 and measured environmental variables describing sediment, topographic and hydrological characteristics

170 of the vegetation sampling plots (list of variables used in Appendix A1). Prior to analysis, species

171 abundance data were Hellinger transformed. Environmental variables were first standardized to zero

172 mean and unit variance. A forward selection procedure was used to identify which of those environmental

173 variables explained the most variance in species composition and abundance. Three separate analyses

174 were performed: all plots included; only plots where sediment variables were sampled (Table 1); only

175 plots where salinity variables were sampled (Table 1).

176 To identify distinct plant associations, a floristic cluster analysis was performed on standardized

177 species abundance data using the Ward's minimum variance clustering method (Ward 1963), which seeks

178 to minimize the sum of squared distances within clustered groups. This technique avoids several problems

179 associated with the more popular TWINSPAN or average-linkage clustering methodologies (see

180 Legendre and Legendre 1998). Formal agglomerative hierarchical clustering, combined with random 
181 sampling avoids bias of initial assumptions made about community structure inherent with many other

182 classification methodologies (Wildi 2010).

183 A meaningful level of dendrogram cutting (i.e., identifying split points among clusters which would

184 differentiate groups) was determined quantitatively. To establish the first criteria for cutting, fusion levels

185 were plotted and the range where clear jumps between levels occurred was identified (Legendre and

186 Legendre 1998, Borcard et al. 2011). Next, silhouette widths were plotted and the optimal number of

187 clusters was determined according to the Rousseeuw quality index (Rousseeuw 1987). Then a silhouette

188 plot of the final partition was created. Group membership and misclassifications were assessed through

189 associated Si values; a measure of grouping validity and relative strength. The square roots of fusion

190 levels were plotted to avoid distension of the dendrogram without altering topology, as recommended by

191 Borcard et al. (2011). Communities were named based on dominance according to CNVC standards at the

192 hierarchical level of the association (CNVC 2013). Indicator Species Analysis was applied to pre-

193 classified vegetation units to determine indicator species. Indicator species are defined as those expressing

194 either dominance (high frequency and abundance) or exclusivity to a given association (Dufrêne and

195 Legendre 1997). To evaluate the adequacy of the sampling methods to detect associations and species, 
196 sampling effort curves were calculated to determine whether the number of associations or species

197 detected reached an asymptote (indicating capture of all associations or species in the sampled areas).

198 Associations and species accumulation were summarized by plots, transects, and sites using 1000

199 randomizations each. All analyses were performed using the open source software R, version 2.15.0 (R

200 Core Team 2013); packages used included "vegan" for PCA, RDA and cluster analyses, "PACKFOR" for

201 forward selection of environmental variables in RDA, "labdsv" for indicator species analysis, and

202 "specaccum" for sampling effort curves.

204 Results

205 Overall species richness, frequency, and abundance

206 Eighty-three vascular plant species were identified across all eight study sites; including 28 graminoids,

20754 forbs and one shrub species (Appendix A2). Forbs contributed the largest percent of species richness,

208 but graminoids were the most frequent and abundant growth form encountered. The only shrub species,

209 Myrica gale L., was identified within two sample plots. 
211 Five clonal graminoid species account for most of the differentiation in species composition and

212 abundance between plots (Fig. 2). Spartina alterniflora and Spartina patens are closely associated in

213 positive score on Axis 1 in the PCA diagram, but widely separated on Axis 2 (Fig. 2a). Carex paleacea

214 Schreb. Ex Wahlenb. exhibits the lowest negative score on Axis 1, followed by centroids of Juncus

215 gerardii Loisel. (high on Axis 3) and Spartina pectinata Link, also projected negatively on Axis 1. C.

216 paleacea and S. pectinata are both at the low end of Axis 3 (Fig. 2b). The rest of the species are not

217 strongly associated with any of the main axes of variation (Appendix A4), so the main community types

218 may be expected to differ mainly in the abundance of these five main graminoid species. Plots at different

219 sites are spread throughout the ordination space, thus there were no plant communities distinct to

220 particular sites. The St. Croix site stands out in being deficient in plots characterized by S. patens and $S$.

221 alterniflora (Fig. 2a), and plots with abundant J. gerardii (high scores on Axis 3) are concentrated at Bass

222 Creek, Cogmagun, and Smith Gut sites (Fig. 2b)

223 Vegetation classification and environmental variables 
224 Seven distinctive plant associations were identified using Ward's minimum variance clustering (Fig. 3;

225 detailed descriptions are in Appendix A7). All but two of these associations are characterized by a single

226 dominant clonal graminoid species, after which the associations are named (Fig. 3, Tables 2 and 3).

227 Species richness varied between six and 40 species per association. The associations generally sort out

228 over gradients of elevation, salinity and inundation (Fig. 4, Table 3). The S. alterniflora association was

229 found at the lowest elevations, with high inundation durations and relatively high salinity (Table 3). The

230 S. patens association was next higher up in elevation and also characterized by relatively long inundation

231 and high soil salinity. Both Distichlis spicata (L.) Greene and Juncus gerardii associations occurred in

232 areas with relatively high elevations and salinities, and low inundation durations; The Carex paleacea

233 association was found in high elevations with low salinity and intermediate inundation durations; the

234 Spartina pectinata association was at similar elevations to the previous, but with lower inundation

235 duration and salinity. The J. balticus-Festuca rubra association had highly variable inundation durations

236 depending on the site and occurred at relatively high elevations and low salinities. Finally, the upland-

237 miscellaneous vegetation was mainly comprised of sample plots located on the upland edge, these often

238 had very low salinity but intermediate inundation frequencies. 
239 The RDA model including all plots explains $16.6 \%$ of variance expressed by species in response to

240 environmental factors (Fig. 4, Appendix A3). Positive RDA axis 1 scores are associated with the tallest

241 measured vegetation heights and the species S. pectinata, C. paleacea, Symphyotrichum novi-belgii (L.)

242 G.L. Nesom. and Agrostis stolonifera L. (Fig. 4a). Negative RDA 2 scores are associated with short

243 inundation time and the species J. gerardii, C. paleacea, S. pectinata, Potentilla anserina ssp. anserina

244 L., Festuca rubra L. and Solidago semprevirens L. Positive RDA 2 scores are associated with long

245 inundation times and the species $S$. alterniflora. Areas dominated by S. patens are thus higher in elevation

246 and have shorter inundation times than areas dominated by S. alterniflora (Fig. 4a, Table 3). The four

247 plots dominated by D. spicata are associated with higher elevations and shorter inundation times

248 compared with $S$. patens (Fig. 4b). J. gerardii is projected at negative RDA 1 and 2 scores, associated

249 with relatively high elevation. When plot subsets where salinity or sediment data were collected were

250 analyzed, patterns in the RDAs were largely consistent with those presented in Table 3 (Appendix A5).

251 Association accumulation curves level off indicating that sampling approximately five sites, 30

252 transects or 75 plots, if selected at random, was necessary to capture all the community types

253 (associations) in the region (Fig. 5). Species accumulation curves show no levelling off at the sampling 
254 intensity in this study (Fig. 5), suggesting that more species may be detected with higher sampling effort

255 within these sites.

256

257 Discussion

258 Salt Marsh Ecology

259 The three main salt marsh communities found (those dominated by S. alterniflora, S. patens, or J.

260 gerardii) are commonly found in low, intermediate and high elevations in New England and New

261 Brunswick (eg., Chmura et al. 1997, Olsen et al. 2005). S. alterniflora is the dominant low marsh species

262 throughout the north-western Atlantic, and is considered to be restricted to high salinity, long inundation

263 conditions due to its competitive inferiority to $S$. patens and other high marsh species (Bertness and

264 Ellison 1987). However, S. alterniflora has been shown experimentally to succeed across the

265 elevation/inundation gradient when competitors are removed (Bertness and Ellison 1987), and was found

266 frequently in plots classified as belonging to the $S$. patens association (Figure 4a). This may reflect wrack

267 or ice disturbance within the $S$. patens zone, leading to small bare patches that can be colonized by $S$. 
268 alterniflora. S. patens is dominant at intermediate elevations, and cannot penetrate lower in the tidal

269 frame due to its inability to oxygenate soils and tolerate longer flooding (Bertness 1991b, Kirwan and

270 Guntenspergen 2012), but is usually kept out of higher elevations as it is outcompeted there by J. gerardii

271 (Bertness 1991a), considered to be a later successional species (Patriquin 1981, Thannheiser 1984) and

272 thought to have a competitive advantage as it begins growth much earlier in the year (Bertness 1991a). $J$.

273 gerardii may also facilitate other species, as shade resulting from its canopy reduces evaporation, keeping

274 the salt concentration from rising and allowing colonization by less salt-tolerant species (Hacker and

275 Bertness 1999). For these communities, most of the subordinate species we found are also present in other

276 marshes further south in the US (Bertness and Ellison 1987, Jacobson and Jacobson 1989).

Although the D. spicata community was only detected at four plots, it was a distinctive community

278 type characterized by similar environmental conditions to the $J$. gerardii community: high elevations,

279 high salinities and low inundation times. This species may colonize disturbances due to ice or wrack

280 deposition in high marsh areas when dominant competitors are killed off (Bertness et al. 1992). Despite

281 intolerance of flooding (Lonard et al. 2013), D. spicata also colonizes areas disturbed by submergence 
282 relating to sea-level rise (Fox et al. 2012). In turn, D. spicata is known to facilitate $J$. gerardii and $S$.

283 patens via reducing substrate salinity (Crain et al. 2008).

284 Although many studies from the east coast of the US report the presence of a distinct vegetation type

285 occurring in pannes created by disturbance to high marsh vegetation (Ewanchuk and Bertness 2004,

286 Griffin et al. 2011), no comparable communities were identified in any of the sites in this study. In

287 general, forb pannes are largely absent from marshes in all three regions of the province, despite the

288 occurrence of large amounts of sea ice causing disturbances in the Bay of Fundy region. We have

289 observed patches of the earlier successional species, Salicornia maritima S.L. Wolff \& Jefferies, but only

290 at disturbed sites. Studies on an outer Bay of Fundy marsh in New Brunswick report widespread Plantago

291 maritima L. in disturbed high marsh areas (Chmura et al. 1997, van Proosdij et al. 1999), but this species

292 was uncommon in sample plots in the current study. Pools containing Zostera marina L. and Ruppia

293 maritima L. have been also found on salt marsh restoration sites in Nova Scotia (Bleakney and Meyer

294 1979, Patriquin 1981). Chapman (1974) considers these to be an early successional stage of the forb

295 pannes found in New England. Patriquin (1981) similarly considers pannes to be a feature of an immature

296 marsh, occurring where poor drainage conditions created by uneven sediment distribution result in the 
297 replacement of S. alterniflora. Of three sample plots included in this study that contained open standing 298 water, one contained $R$. maritima and was numerically allocated to the miscellaneous grouping of plots

299 that were otherwise associated with upland conditions.

Less is known about the distribution and environmental relationships of brackish communities. Juncus

301 balticus is reported as occurring at the terrestrial edge of the high marsh (S. patens, J. gerardii

302 communities) in Bay of Fundy sites (Chapman 1974, Chmura et al. 1997), and occurred in all three study

303 regions, but is seldom mentioned as a component of tidal marshes in other studies. This may represent a

304 community that is more common in more northern, west Atlantic tidal marshes (Thannheiser 1984). $C$.

305 paleacea is found in Maine tidal marshes with significant freshwater influence, as is S. pectinata

306 (Jacobson and Jacobson 1989), but that study did not detect J. balticus at all. While previous work in

307 Nova Scotia identifies the C. paleacea community as a high marsh community type (Pielou and Routlege

308 1976, Thannheiser 1984), there is almost no mention of S. pectinata, which is a common component of

309 brackish areas in the marshes studied. Here it appears that, while the "brackish" communities identified

310 are all characterized by intermediate salinities (9-12 ppt), the C. paleacea community is characterized by

311 longer inundation times than $S$. pectinata, and the $J$. balticus-F. rubra community appears at the highest 
312 elevations/shortest inundation times of the three. The C. paleacea community is also characterized by the

313 highest organic matter content (Table 3), which likely reflects high rates of peat production. Carbon

314 storage by tidal marshes is determined in part by the net rate of organic matter production in the soil

315 (Chmura 2013) and thus the persistence of this plant association may be important to the overall value of

316 tidal marshes in the province. Further studies of belowground productivity are warranted to compare the

317 potential of these different community types as carbon sinks.

318 We were able to differentiate between distinct associations documented at the same elevation and

319 relate these to salinity and inundation. In tidal freshwater wetlands and marsh edges, tidal variability is

320 high and the influence of freshwater input also varies seasonally thus affecting transport of sediments and

321 nutrients, as well as salinity and acts as a constraint on plant growth (Flynn et al. 1995, Pont et al. 2002,

322 Neubauer 2013). Gradients of inundation and salinity appear to be at least partially independent, with

323 high salinities occurring at a range of inundation times. For example, the $J$. gerardii association is found

324 at relatively short inundation durations similar to $S$. pectinata, but with much higher substrate salinity

325 (Table 3). This is consistent with literature in which $J$. gerardii is considered to be species typical of high

326 salt marsh (polyhaline) (eg., Chapman 1974), whereas S. pectinata and C. paleacea are considered 
327 brackish or mesohaline species. Plant species also show independent variation to both gradients. For

328 example, Egan and Unger (2000) found that highly salt-tolerant species differed greatly in their tolerance

329 to inundation. Given the scarcity of published literature on marsh edge and brackish communities $(J$.

330 balticus - F. rubra and S. pectinata), and because salinity did not always correlate with elevation and

331 inundation time, restoration managers in the region are recommended to incorporate more salinity

332 sampling into their monitoring programs in order to predict vegetation dynamics.

333 Sediment variables show similar patterns to those reported in other studies (DeLaune et al. 1979,

334 Crooks et al. 2002, van Proosdij et al. 2010), with relatively fine particles and high bulk density

335 associated with low marsh (S. alterniflora associations), and brackish associations with greater organic

336 content and lower bulk densities. Vegetation height was included as an environmental variable in the

337 redundancy analysis as an index of productivity, but this may be valid only within a species (Fox et al.

338 2012) and using these results only as descriptors of the communities is recommended. Other variables

339 such as redox potential and nutrient levels may also affect plant community composition (Bertness and

340 Ellison 1987, Davy et al. 2011, Fox et al. 2012), but were not measured in this study and may provide

341 further resolution to the plant community patterns detected here. Likewise, disturbances caused by 
342 grazing, ice scour and deposition of vegetation mats could also affect distribution of species (Schröder et

343 al. 2002, Hulzen et al. 2006), especially subordinates, which did not respond strongly to the measured

344 environmental gradients here.

345 Regional Variation

346 In general, many of the same associations were found on all three coastlines within the region, despite

347 large differences in elevation and tidal characteristics between Fundy and the other two coasts (Table 3).

348 The association accumulation curves suggest that the sampling methods were adequate to detect all

349 associations at the sites. Both the Atlantic and Northumberland Strait Regions are characterized by much

350 lower tidal amplitude than the Bay of Fundy but the relative position of the different associations along

351 the elevation gradient is similar across all three coasts (Table 3), suggesting that the dominant plant

352 species are responding to the same ecological processes in all the regions. In general, more sampling of

353 Northumberland Strait and Atlantic wetlands is necessary to confirm the generality of patterns we

354 observed in this study. 
356 The sites sampled here are representative of reference conditions for tidal marshes in the region.

357 Succession in tidal marshes has been described in the region (Chapman 1974, Patriquin 1981), but not

358 quantitatively studied in Nova Scotia, with the exception of recovery trajectories in restored marshes

359 (Byers and Chmura 2007, Van Proosdij et al. 2010). The sites described here represent mature

360 communities where vegetation zonation is relatively stable due to the lack of current anthropogenic

361 disturbances. These communities have been recognized as relatively stable over hundreds of years in New

362 England (Miller and Egler 1950).

363 Primary succession in salt marshes in the region is considered to consist of colonization of a site by $S$.

364 alterniflora followed by accretion of sediment, and later differentiation into low marsh (dominated by $S$.

365 alterniflora) and high marsh (dominated by S. patens). We have now recognized other high marsh types

366 as separate associations, but their successional trajectories are not known. The occurrence of these

367 different salt marsh types may relate to ecological factors such as the relative ability to colonize after

368 disturbances (e.g. Bertness and Ellison 1987) and the relative frequency of small disturbances caused by

369 ice or wrack deposition, which were not quantified in our study. Secondary succession in these systems

370 has been hypothesized to consist of salt marsh annuals, followed by recolonization by S. alterniflora or 
371 high marsh species at higher elevations. We did not detect communities dominated by annuals in this

372 study, but have observed these at restoration sites, where bare mud is much more common. In New

373 England, such patches are usually recolonized by perennials within three years (Bertness and Ellison

374 1987).

375 Ecological restoration of tidal wetlands in Nova Scotia has proceeded using a paired-reference site

376 approach, where each site under restoration is compared with an intact or reference marsh nearby

377 (Bowron et al. 2012). When the nearest intact marsh has a different range of environmental conditions

378 than the restoration site, this can complicate predictions of vegetation zonation and the relative proportion

379 of plant associations as recovery proceeds (van Proosdij et al. 2010). Now that the elevation ranges have

380 been quantified and other environmental characteristics of the tidal wetland communities described it may

381 be possible to build a reference condition model for tidal wetlands in each region. This would enable

382 restoration efforts to progress to a multiple-reference site approach where vegetation plots from a regional

383 set of pre-established reference sites can be matched with plots at restoration sites that have similar

384 environmental conditions (Reynoldson et al. 1997, Westhead 2005), resulting in cost savings. 
upland communities. The ability for tidal marsh communities to migrate landward and persist depends on

387 sediment supply, the tidal range of the site and the distribution of elevations (Chmura 2013) and lack of

388 anthropogenic barrier (e.g. road or dyke) (Ponte 2013). This study presents baseline information (e.g.

389 ranges of environmental variables) describing plant communities and their environmental correlates,

390 needed to predict response to climate change (Warren and Niering 1993, Gedan and Bertness 2009,

391 Hladic and Alber 2014). In the face of sea level rise and increasing inundation, we can predict that these

392 communities will shift inland, with the relative extent of different zones depending to a large extent on

393 site-specific elevation distributions, the existence of natural habitats (as opposed to built structures) into

394 which tidal march communities can migrate, and hydrological influences (Byers and Chmura 2014),

395 including the amount of freshwater influencing the marsh in its new tidal range.

396 This paper was the first to use quantitative methods to classify Nova Scotia tidal wetland communities

397 and link plant community composition with environmental gradients. This study provides resolution of

398 the brackish associations at the oligohaline ends of the salinity gradients. This information can facilitate 
399 adoption of a multiple reference site approach, with a strong baseline for studies on the restoration,

400 monitoring and management of coastal wetlands in the region.

401

402 Acknowledgments

403 We thank Greg Baker of the MP_SpARC lab for assistance with map-making and GIS analysis. Funding

404 for this project was provided by a grant from the Nova Scotia Department of Economic and Rural

405 Development and Tourism, Strategic Cooperative Education Incentive to CBWES, and an NSERC

406 Discovery grant to J. Lundholm.

407

408 References

409 Atlantic Canada Conservation Data Center (ACCDC). 2015. Species Conservation Ranks. [online].

410 Available from http://www.accdc.com/en/ranks.html [accessed February 26 2015].

411 Bertness, M.D.1991a. Interspecific interactions among high marsh perennials in a New England salt

412 marsh. Ecology, 72(1): 125- 137. doi: 10.2307/1938908. 
413 Bertness, M.D. 1991b. Zonation of Spartina patens and Spartina alterniflora in a New England salt

414 marsh. Ecology, 72: 138-148. doi: 10.2307/1938909.

415 Bertness, M.D., and Ellison, A.M. 1987. Determinants of pattern in a New England salt marsh plant

416 community. Ecol. Monogr. 57(2): 129-147. doi: 10.2307/1942621

417 Bertness, M.D., Gough, L. and S. W. Shumway. 1992. Salt tolerances and the distribution of fugitive salt

418 marsh plants. Ecology, 73: 1842-1851

419 Bleakney, J.,S., and Meyer, K.B. 1979. Observations on Saltmarsh pools, Minas Basin, Nova Scotia

420 1965-1977. Proc. Nova. Scot. Inst. Sci. 29: 353-371.

421 Blott, S.J., and Pye, K. 2001. Gradistat: A grain size distribution and statistics package for the analysis of unconsolidated sediment. Earth Surf. Process. Landf. 26(11): 1237-1248. doi: 10.1002/esp.26.

423 Borcard, D., Gillet, F., and Legendre, P. 2011. Numerical Ecology with R. Springer, New York.

424 Bowron, T., Neatt, N., van Proosdij, D., Lundholm, J., and Graham, J. 2011. Macro-tidal salt marsh

425 ecosystem response to culvert expansion. Restor. Ecol. 19(3): 307-322. doi:10.1111/j.1526- 
427 Bowron, T., Neatt, N., van Proosdij, D., Lundholm, J., and Graham, J. 2012. Salt marsh tidal restoration

428 in Canada's Maritime Provinces. In Tidal Marsh Restoration: A Synthesis of Science and

429 Management. Edited by C.T. Roman, and D. M. Burdick. Island Press, Washington, D.C. pp. 191-

$430 \quad 209$.

431 Byers, S., and Chmura, G. 2007. Salt Marsh Vegetation Recovery on the Bay of Fundy. Estuaries Coasts,

432 30: 869-877. doi: 10.1007/BF02841340

433 Byers, S., and Chmura, G. 2014. Observations on Shallow Subsurface Hydrology at Bay of Fundy

434 Macrotidal Salt Marshes. J. Coastal Res. 30(5): 1006-1016.

435 doi: http://dx.doi.org/10.2112/JCOASTRES-D-12-00167.1

436 Canadian National Vegetation Classification (CNVC). 2013. [online] Available from http://cnvc-cnvc.ca

$437 \quad$ [accessed 6 January 2014].

438 Chapman, V.J. 1937. A note on salt marshes of Nova Scotia. Rhodora, 39: 53-7.

439 Chapman. V J. 1974. Salt marshes and salt deserts of the world. Second, supplemented reprint edition.

$440 \quad$ Phylis Claire Chapman, Germany. 
441 Chmura, G., Chase, P., and Bercovitch, J.1997. Climatic controls of the middle marsh zone in the Bay of

442 Fundy. Estuaries, 20(4): 689-699. doi: 10.2307/1352244.

443 Chmura, G. 2013. What do we need to assess the sustainability of the tidal salt marsh carbon sink? Ocean

$444 \quad$ Coast Manage. 83: 25-31. doi:10.1016/j.ocecoaman.2011.09.006

445 Craft, C., Clough, J., Ehman, J., Joye, S., Park, S., Pennings, S., Guo, H., and Machmuller, M. 2009.

$446 \quad$ Forecasting the effects of accelerated sea-level rise on tidal marsh ecosystem services. Front. Ecol.

447 Environ. 7(2): 73-78. doi: 10.1890/070219.

448 Crain, C. 2008. Interactions between marsh plant species vary in direction and strength depending on

449 environmental and consumer context. J. Ecol. 96: 166-173. doi:10.1111/j.1365-2745.2007.01314.x

450 Crooks, S., Schutten, J., Sheern, G.D., Pye, K., and Davy, A.J. 2002. Drainage and elevation as factors in

451 the restoration of salt marsh in Britain. Restor. Ecol. 10(3): 591-602. doi: 10.1046/j.1526-

$452 \quad$ 100X.2002.t01-1-02036.x. 
453 Davy, A., Brown, M., Mossman, H., and Grant, A. 2011. Colonization of a newly developing salt marsh:

454 Disentangling independent effects of elevation and redox potential on halophytes. J. Ecol. 99(6):

455 1350-1357. doi: 10.1111/j.1365-2745.2011.01870.x

456

DeLaune, R.D., Buresh, R.J., and Patrick, W.H. Jr.1979. Relationship between soil properties to standing

457 crop biomass of Spartina alterniflora in a Louisiana Marsh. Estuar. Coast. Shelf Sci. 8(5): 477-487. doi: 10.1016/0302-3524(79)90063-X.

459 Dufrêne, M., and Legendre, P. 1997. Species assemblages and indicator species: the need for a flexible asymmetrical approach. Ecol. Monogr. 67(3): 345-366. doi: 10.2307/2963459.

461 Egan, T.P., and Ungar, I.A. 2000. Mortality of the salt marsh species Salicornia europea and Atriplex

462 prostrata (Chenopodiaceae) in response to inundation Ohio J. Sci. 100(2): 24-27.

463 Ewanchuk, P., and M. Bertness. 2004. Structure and organization of a northern New England salt marsh

464 plant community. J. Ecol. 92(1): 72-85. doi: 10.1111/j.1365-2745.2004.00838.x.

465 Fernald, M.L. 1920. The Gray Herbarium Expedition to Nova Scotia. Contributions from the Gray

466 Herbarium of Harvard University 63: 89-111, 130-171, 184-195, 223-245, 257-278, 284-300. 
467 Fielding, R. 2001. Baccharis: A Genus of the Asteraceae New to Canada. Proc. Nova. Scot. Inst. Sci. 41:

214-215.

469 Flynn, K., McKee, K., and Mendelssohn, I. 1995. Recovery of freshwater marsh vegetation after a

470 saltwater intrusion event. Oecologia, 103(1): 63-72. doi: 10.1007/BF00328426

471 Fox, L., Valiela, I., and Kinney, E.L. 2012. Vegetation cover and elevation in long-term experimental

472 nutrient-enrichment plots in Great Sippewissett Salt Marsh, Cape Cod, Massachusetts: Implications for

473 eutrophication and sea level rise. Estuaries Coasts, 35(2): 445-458. doi: 10.1007/s12237-012-9479-x

474 Ganong, W.F. 1903. The Vegetation of the Bay of Fundy Salt and Diked Marshes: An Ecological Study.

475 Bot. Gaz. 36: 161-186, 280-302, 349-369, 429-455.

476 Gedan, K.B., and Bertness, M.D., 2009. Experimental warming causes rapid loss of plant diversity in

477 New England salt marshes. Ecol. Lett. 12(8): 842-848. Doi: 10.1111/j.1461-0248.2009.01337.x

478 Griffin, P.J., Tehodose, T., and Dionne, M. 2011. Landscape patterns of form pannes across a northern 

and Bertness, M.D. 1999. Experimental evidence for factors maintaining plant species diversity in a New England salt marsh. Ecology, 80 (6): 2064-2073.

482 Hanson, A. R., and Calkins, L. 1996. Wetlands of the Maritime Provinces: Revised Documentation for the Wetlands Inventory. Canadian Wildlife Service, Atlantic Region, Sackville, New Brunswick, Canada. Technical Report No. 267. 
493 Jacobson, A., and Jacobson, L. 1989. Variability of vegetation in tidal marshes of Maine, U.S.A. Can. J.

494 Bot. 67(1): 230-238. doi: 10.1139/b89-032

495 Kirwan, M.L., and Guntenspergen, G.R.. 2012. Feedbacks between inundation, root production, and shoot

496 growth in a rapidly submerging brackish marsh. J. Ecol. 100: 764-770. doi:10.1111/j.1365-

$497 \quad 2745.2012 .01957 . x$

498 Legendre, P., and Gallagher, E. 2001. Ecologically meaningful transformations for ordination of species

499 data. Oceologia, 129(2): 271-280. doi: 10.1007/s004420100716.

500 Legendre, P., and Legendre, L.1998. Numerical Ecology: Second English Edition, Developments in

501 Environmental Modelling, 20. Elsevier, New York.

502 Lonard, R.I., Judd, F.W., and Stalter, R. 2013. The biological flora of coastal dunes and wetlands:

503 Distichlis spicata (C. Linnaeus) E. Greene. J. Coastal Res. 29(1): 105-117.

504 doi: http://dx.doi.org/10.2112/JCOASTRES-D-12-00018.1 
505 McAloney, K. 1981. Waterfowl use of Nova Scotian salt marshes. In Salt marshes in Nova Scotia. Edited

506 by A. Hatcher and D. G. Patriquin. Institute for Resource and Environmental Studies and Department

507 of Biology, Dalhousie University, Halifax. pp. 60-66.

508 Miller, W.B., and Egler, F.E. 1950. Vegetation of the Wequetequock-Lawcatuck tidal marshes,

509 Connecticut. Ecol. Monogr. 20: 143-172. doi: 10.2307/1943548

510 Neckles, H.A., Dionne, M., Burdick, D.M., Roman, C.T., Buchsbaum, R., and Hutchins. E. 2002. A

511 monitoring protocol to assess tidal restoration of salt marshes on local and regional scales. Restor.

512 Ecol. 10(3): 556-563. doi: 10.1046/j.1526-100X.2002.02033.x.

513 Neubauer, S.C. 2013. Ecosystem response of a tidal freshwater marsh experiencing saltwater intrusion

514 and altered hydrology. Estuaries Coasts, 36(3): 491-507. doi: 10.1007/s12237-011-9455-x.

515 Olsen, L., Ollerhead, J., and Hanson, A. 2005. Relationships between plant species’ zonation and

516 elevation in salt marshes of the Bay of Fundy and Northumberland Strait. Proceedings of the Canadian

$517 \quad$ coastal conference. New Brunswick. 
518 Patriquin, D. 1981. The General Biology of Salt Marshes. In: Salt Marshes in Nova Scotia. Edited by A.

519 Hatcher and D. G. Patriquin. Institute for Resource and Environmental Studies and Department of

520 Biology, Dalhousie University, Halifax. pp. 4-31.

521 Peel, M.C., Finlayson, B.L. and McMahon, T.A. 2007. Updated world map of the Köppen-Geiger climate

522 classification. Hydrol. Earth Syst. Sc. 4(2): 439-473.

523 Pennings, S., and Callaway, R. 1992. Salt Marsh Plant Zonation: The Relative Importance Of

524 Competition And Physical Factors. Ecology, 73(2): 681-690. doi: 10.2307/1940774.

525 Pennings, S., Grant, M., and Bertness, M. 2005. Plant zonation in low-latitude salt marshes: disentangling

526 the roles of flooding, salinity and competition. J. Ecol. 93(1): 159-167. doi: 10.1111/j.1365-

$527 \quad 2745.2004 .00959 . x$.

528 Pielou, E.C., and Routledge, R.D. 1976. Salt marsh vegetation: Latitudinal gradients in the zonation

529 patterns. Oecologia, 24(4): 311-321. 
530 Pont, D., Simonnet, J.P., and Walter. A.V. 2002. Medium-term changes in suspended sediment delivery

531 to the ocean: consequences of catchment heterogeneity and river management (Rhône River, France).

532 Estuar. Coast. Shelf S. 54(1): 1-18. doi: 10.1006/ecss.2001.0829.

533 Ponte, N. 2013. Defining coastal squeeze: A discussion. Ocean Coast. Manage. 84 (11): 204-207.

534 doi:10.1016/j.ocecoaman.2013.07.010

535 R Core Team. 2013. R: A Language and Environment for Statistical Computing. Vienna, Austria.

536 [online]. Available from http://www.R-project.org/. [accessed Jan 3 2013].

537 Reynoldson, T.B., Rosenberg, D.R., Day, K.E., Norris, R.H., and Resh, V.H. 1997. The reference

538 condition: A comparison of multimetric and multivariate approaches to assess water-quality

539 impairment using benthic macroinvertebrates. J. N. Am. Benthol. Soc. 16(4): 833-852.

$540 \quad$ doi: $10.2307 / 1468175$.

541 Roberts, B.A., and Robertson, A. 1986. Salt Marshes of Atlantic Canada: their ecology and distribution.

542 Can. J. Bot. 64(2): 455-467. doi: 10.1139/b86-060. 
543 Roman, C.T., Raposa, K.B., Adamowicz, S.C., James-Pirri, M.J., and Catena, J.G. 2002. Quantifying

544 vegetation and nekton response to tidal restoration of a New England salt marsh. Restor. Ecol. 10(3):

545 450-460. doi: 10.1046/j.1526-100X.2002.01036.x.

546 Rousseeuw, P. 1987. Silhouettes: A graphical aid to the interpretation and validation of cluster analysis.

547 Compu. Appl. Math. 20: 53-65. doi: 10.1016/0377-0427(87)90125-7.

548 Schröder, H.K., Kiehl, K., and Stock, M. 2002. Directional and non $\square$ directional vegetation changes in a

549 temperate salt marsh in relation to biotic and abiotic factors. Appl. Veg. Sci. 5(1): 33-44.

550 doi: 10.1111/j.1654-109X.2002.tb00533.x

551 Singh, K., Walters, B.B., and Ollerhead, J. 2007 Climate change, sea-level rise and the case for salt marsh

552 restoration in the Bay of Fundy, Canada. Environments. 35(2): 71-84.

553 Thannheiser, D. 1984. The coastal vegetation of eastern Canada. Occasional Papers in Biology No 8.

554 Memorial University of Newfoundland, St. John's, Newfoundland, Canada.

555 Tonis, I.E., Stam, J.M.T., and van de Graaf, J. 2002. Morphological changes of the Haringvliet estuary

556 after closure in 1970. Coast. Eng. 44(3): 191-203. doi: 10.1016/S0378-3839(01)00026-6. 
557 van Proosdij, D., Ollerhead, J., Davidson-Arnott, R.G.D., and L. Schostak. 1999. Allen Creek Marsh, 558 Bay of Fundy: a macro-tidal coastal saltmarsh. Can. Geogr. 43: 316-322.

559 van Proosdij, D., Lundholm, J., Neatt, N., and Bowron, T. 2010. Ecological re-engineering of a

560 freshwater impoundment for salt marsh restoration in a hypertidal system. Ecol. Eng. 36(1): 1314-

561 1332. doi: $10.1016 /$ j.ecoleng.2010.06.008.

562 Ward, J. 1963. Hierarchical grouping to optimize an objective function. J. Am. Stat. Assoc. 58(301): 236244. doi:10.1080/01621459.1963.10500845

564 Warner, B., and Rubec, C. 1997. The Canadian Wetland Classification System. Second Edition. Canadian 565 Wildlife Service, Environment Canada, Ottawa, Ontario, Canada.

566 Warren, R.S., and Niering, W.A. 1993. Vegetation change on a Northeast tidal marsh: interaction of sea-

567 level rise and marsh accretion. Ecology, 74: 96- 103. http://dx.doi.org/10.2307/1939504

568 Westhead, M.C. 2005. Investigations of the Reference Condition Approach and intertidal ecology of the

569 Minas Basin, Bay of Fundy, with reference to the impacts of intertidal harvesting. M.Sc. Thesis.

570 Acadia University, Wolfville, Nova Scotia. 
571 Wildi, O. 2010. Data Analysis in Vegetation Ecology. Wiley-Blackwell, Oxford, UK.

572 Zedler, J.B., Callaway, J.C., Desmond, J.S., Vivian-Smith, G., Williams, G.D., Sullivan, G., Brewster,

573 A.E., and Bradshaw, B.K. 1999. Californian salt-marsh vegetation: an improved model of spatial

574 pattern. Ecosystems, 2(1): 19-35. doi: 10.1007/s100219900055.

575 Zoltai, S., and Vitt, D. 1995. Canadian wetlands: Environmental gradients and classification. Vegetatio,

576 118(1): 131-137. doi: 10.1007/BF00045195.

577 


\section{Tables}

579 Table 1. Study site location, site elevation and sample size.

\begin{tabular}{|c|c|c|c|c|c|c|}
\hline \multirow[b]{2}{*}{ Site } & \multirow[b]{2}{*}{ GPS Location (UTM) } & \multicolumn{2}{|c|}{ Site Elevation (m) } & \multicolumn{3}{|l|}{ Sample Size } \\
\hline & & Mean & Range & Vegetation & Salinity & Sediment \\
\hline Cogmagun River* & $412096 \mathrm{E}, 4992816 \mathrm{~N}$ & 6.68 & $4.86-7.25$ & 23 & 8 & 7 \\
\hline Walton River* & $421950 \mathrm{E}, 5008087 \mathrm{~N}$ & 6.18 & $4.62-7.25$ & 28 & 5 & 3 \\
\hline Walton Fringe* & 422407E, 5007824N & 5.62 & $4.28-6.95$ & 13 & 0 & 0 \\
\hline Bass Creek* & $410990 \mathrm{E}, 5005715 \mathrm{~N}$ & 5.77 & $4.22-6.57$ & 25 & 5 & 17 \\
\hline Smith Gut $\uparrow$ & $547844 \mathrm{E}, 5055018 \mathrm{~N}$ & 0.72 & $0.22-0.89$ & 20 & 5 & 6 \\
\hline Lawrencetown $\ddagger$ & $472402 \mathrm{E}, 4943514 \mathrm{~N}$ & 0.58 & $0.37-0.77$ & 24 & 6 & 5 \\
\hline St. Croix* & $419838 \mathrm{E}, 4984888 \mathrm{~N}$ & 7.42 & $5.31-8.74$ & 19 & 6 & 6 \\
\hline St. Croix Fringe* & $418642 \mathrm{E}, 4980339 \mathrm{~N}$ & 6.38 & $4.84-8.06$ & $\begin{array}{l}13 \\
(n=165)\end{array}$ & $\begin{array}{l}0 \\
(n=35)\end{array}$ & $\begin{array}{l}1 \\
(n=45)\end{array}$ \\
\hline
\end{tabular}

$580 *$ Bay of Fundy, $\uparrow$ Northumberland, $¥$ Atlantic Coast, GPS coordinates are provided in UTM, Zone

$581 \quad$ 20NNAD 84 
583 Table 2. Indicator Species of tidal marsh vegetation associations.

\begin{tabular}{lllll}
\hline Association & Indicator Species & $\begin{array}{l}\text { Indicator } \\
\text { value* }\end{array}$ & $\begin{array}{l}\text { Frequency } \\
\%\end{array}$ \\
\hline Spartina alterniflora Salt Marsh & Spartina alterniflora & 0.68 & 0.001 & 100 \\
Spartina patens Salt Marsh & Spartina patens & 0.50 & 0.001 & 100 \\
Distichlis spicata Salt Marsh & Distichlis spicata & 0.92 & 0.001 & 100 \\
Juncus gerardii Salt Marsh & Juncus gerardii & 0.75 & 0.001 & 100 \\
Carex paleacea Brackish Marsh & Carex paleacea & 0.61 & 0.001 & 100 \\
Juncus balticus-Festuca rubra Brackish Marsh & Juncus balticus & 0.68 & 0.001 & 67 \\
& Festuca rubra & 0.56 & 0.001 & 80 \\
& Anthoxanthum nitens & 0.29 & 0.01 & 40 \\
& Scutellaria galericulata. & 0.26 & 0.006 & 27 \\
Spartina pectinata Brackish Marsh & Myrica gale & 0.14 & 0.03 & 13 \\
Upland-Miscellaneous & Carex hormathodes & 0.14 & 0.042 & 13 \\
& Spartina pectinata & 0.83 & 0.001 & 100 \\
& Taraxacum officinale & 0.40 & 0.002 & 40 \\
& Galium palustre & 0.34 & 0.008 & 45 \\
& Equisetum arvense & 0.28 & 0.014 & 35 \\
& Poa pratensis & 0.24 & 0.003 & 20 \\
& Solidago canadensis & 0.19 & 0.014 & 35 \\
& Solidago gigantea & 0.19 & 0.038 & 20 \\
& Bromus inermis & 0.14 & 0.05 & 10 \\
& Centaurea nigra & 0.14 & 0.042 & 15 \\
\hline
\end{tabular}


586 Table 3. Summary of environmental characteristics of tidal marsh vegetation associations.

\begin{tabular}{|c|c|c|c|c|c|c|c|c|c|}
\hline \multirow[b]{2}{*}{ Association } & & \multicolumn{4}{|l|}{ Salt Marsh } & \multicolumn{3}{|c|}{ Brackish Marsh } & Upland \\
\hline & & $\begin{array}{l}\text { Spartina } \\
\text { alterniflora }\end{array}$ & $\begin{array}{l}\text { Spartina } \\
\text { patens }\end{array}$ & $\begin{array}{l}\text { Distichlis } \\
\text { spicata }\end{array}$ & $\begin{array}{l}\text { Juncus } \\
\text { gerardii }\end{array}$ & $\begin{array}{l}\text { Carex } \\
\text { paleacea }\end{array}$ & $\begin{array}{l}\text { Spartina } \\
\text { pectinata }\end{array}$ & $\begin{array}{l}\text { Juncus } \\
\text { balticus- } \\
\text { Festuca } \\
\text { rubra }\end{array}$ & $\begin{array}{l}\text { Upland and } \\
\text { miscellaneous }\end{array}$ \\
\hline \multirow{3}{*}{$\begin{array}{l}\text { Mean elevation ( } m \text { relative to } \\
\text { CGVD28 vertical datum } \pm \text { SE) }\end{array}$} & Fundy & $5.15 \pm 0.13$ & $6.05 \pm 0.10$ & $6.24 \pm 0.34$ & $6.73 \pm 0.11$ & $6.54 \pm 0.21$ & $6.49 \pm 0.23$ & $7.13 \pm 0.17$ & $6.98 \pm 0.43$ \\
\hline & Atl. & $0.42 \pm 0.02$ & $0.58 \pm 0.02$ & & & $0.62 \pm 0.02$ & 0.67 & $0.70 \pm 0.02$ & \\
\hline & North. & $0.33 \pm 0.11$ & & & & $0.71 \pm 0.03$ & $0.82 \pm 0.03$ & $0.78 \pm 0.02$ & \\
\hline \multirow{3}{*}{ Elevation range (m) } & Fundy & $4.22-6.32$ & $4.32-6.68$ & $5.36-6.65$ & $5.7-7.19$ & $5.24-7.366$ & $5.18-7.48$ & $6.48-7.72$ & $4.84-8.74$ \\
\hline & Atl. & $0.37-0.49$ & $0.49-0.64$ & & & $0.59-0.67$ & & $0.66-0.77$ & \\
\hline & North. & $0.22-0.44$ & & & & $0.52-0.81$ & $0.66-0.89$ & $0.74-0.79$ & \\
\hline \multirow{3}{*}{$\begin{array}{l}\text { Mean inundation time (minutes* } \\
\pm \text { SE) }\end{array}$} & Fundy & $143.2 \pm 5.5$ & $111.2 \pm 4.0$ & $105.2 \pm 11.0$ & $80.6 \pm 5.3$ & $91.6 \pm 9.0$ & $85.7 \pm 8.3$ & $57.5 \pm 12.3$ & $101.3 \pm 31.8$ \\
\hline & Atl. & $416.2 \pm 10.3$ & $351.7 \pm 9.5$ & & & $330.5 \pm 8.4$ & 314.7 & $301.1 \pm 8.3$ & \\
\hline & North. & $366.2 \pm 51.1$ & & & & $182.1 \pm 15.8$ & $139 \pm 10.5$ & $153.2 \pm 5.2$ & \\
\hline Mean pore water salinity $( \pm \mathrm{SE})$ & $(\mathrm{ppt})$ & $18.2 \pm 1.7$ & $20.0 \pm 1.7$ & 21.6 & $21.6 \pm 3.0$ & $12.4 \pm 1.3$ & $9.54 \pm 1.24$ & $9.3 \pm 4.5$ & $0.7 \pm 0.4$ \\
\hline Mean particle size $( \pm \mathrm{SE})$ & (microns) & $8.86 \pm 0.32$ & $9.50 \pm 0.56$ & 8.19 & $9.84 \pm 0.90$ & $16.73 \pm 5.79$ & $30.17 \pm 16.6$ & $17.45 \pm 6.23$ & $8.20 \pm 0.09$ \\
\hline Mean sediment organic matter & $(\%)$ & $6.66 \pm 0.40$ & $19.40 \pm 4.67$ & 15.42 & $14.61 \pm 1.35$ & $31.72 \pm 7.10$ & $15.87 \pm 4.83$ & $24.82 \pm 7.82$ & $14.13 \pm 5.83$ \\
\hline
\end{tabular}




\begin{tabular}{|c|c|c|c|c|c|c|c|c|c|}
\hline Mean sediment dry bulk density & $(\mathrm{g} * \mathrm{~cm}-3)$ & $0.81 \pm 0.04$ & $0.49 \pm 0.10$ & 0.83 & $0.66 \pm 0.07$ & $0.31 \pm 0.07$ & $0.65 \pm 0.15$ & $0.44 \pm 0.15$ & $0.72 \pm 0.30$ \\
\hline Mean vegetation height & $(\mathrm{cm})$ & $106 \pm 7$ & $52 \pm 2$ & $59 \pm 5$ & $44 \pm 2$ & $87 \pm 7$ & $142 \pm 9$ & $75 \pm 13$ & $96 \pm 14$ \\
\hline
\end{tabular}

$587 *$ Average number of minutes plot is flooded during flooding events (ie., hydroperiod in minutes divided by inundation frequency in number of events). 


\section{Figure Captions}

589 Figure 1. Map showing locations of study sites. Redrawn from data provided by Natural Resources 590 Canada; no permission required, see: https://www.nrcan.gc.ca/terms-conditions/10847 ; information 591 licensed under the Open Government Licence - Canada. http://open.canada.ca/en/open-government592 licence-canada

593 Figure 2. Principal components analysis of species abundance in tidal marsh plots. Axes 1-3 explain $59425 \%, 18 \%$ and $12 \%$ of the variance in species composition/abundance respectively. a) Axes 1 and 2; 595 Spartina alterniflora and $S$. patens centroids are found at the coordinates $(0.998,0.978)$, and $(0.978,1.01)$ 596 respectively; central polygon contains all other species' centroids (Fig. S3) b)) Axes 1 and 3; $S$. 597 alterniflora, $S$. patens and J. gerardii centroid coordinates: $(0.998,0.0535),(0.978,-0.217),(-0.309,0.998)$ 598 respectively; Species' centroids indicated by abbreviations (Table S1). Major species: car.pal = Carex 599 paleacea $;$ jun.ger $=$ Juncus gerardii; spa.alt $=$ Spartina alterniflora $;$ spa. pat $=$ Spartina patens $;$ spa.pec $=$ 600 Spartina pectinata.

601 Figure 3. Classification of tidal marsh vegetation. Height represents the dissimilarity index of the Ward's 602 minimum variance clustering method. General descriptions of environmental characteristics represent a 603 synthesis of RDA results (see Fig. 4) and average values of environmental variables described in the text 604 (Table 3). Right side contains association names in bold, followed by the number of plots classified into 605 each group (n), Si is the silhouette value, an index of within-group similarity (stronger positive scores = 606 more similar), and total number of species (spp.) found in the plots classified into each group.

607 Figure 4. Redundancy analyses of species abundance in tidal marsh plots, with environmental variables; 608 plots labelled using plant associations determined using Ward's minimum variance clustering. All plots, 609 environmental variables included: elev = plot elevation; inun.time = amount of time plot is inundated; 610 veg.height $=$ height of vegetation; Axes 1-3 explain 9.8\%, 5.6\% and 2.2\% of the variance in species 611 composition in response to environmental variables, respectively. a) Axes 1 and 2; b) Axes 1 and 3. 612 Central polygons contain all other species centroids. Major species: car.pal $=$ Carex paleacea; jun.ger $=$ 613 Juncus gerardii; spa.alt = Spartina alterniflora; spa.pat = Spartina patens; spa.pec $=$ Spartina pectinata; 614 hie.odo = Anthoxanthum nitens; fes.rub = Festuca rubra; pot.ans = Potentilla anserina; sym.nov = 615 Symphotrichum novi-belgii; agr.sto = Agrostis stolonifera

616 Figure 5. Sampling effort-association accumulation curves ((a)-(c)) for sites, transects and plots. 617 Sampling effort-species accumulation curves ((d)-(f)). Polygons show 95\% confidence intervals. 


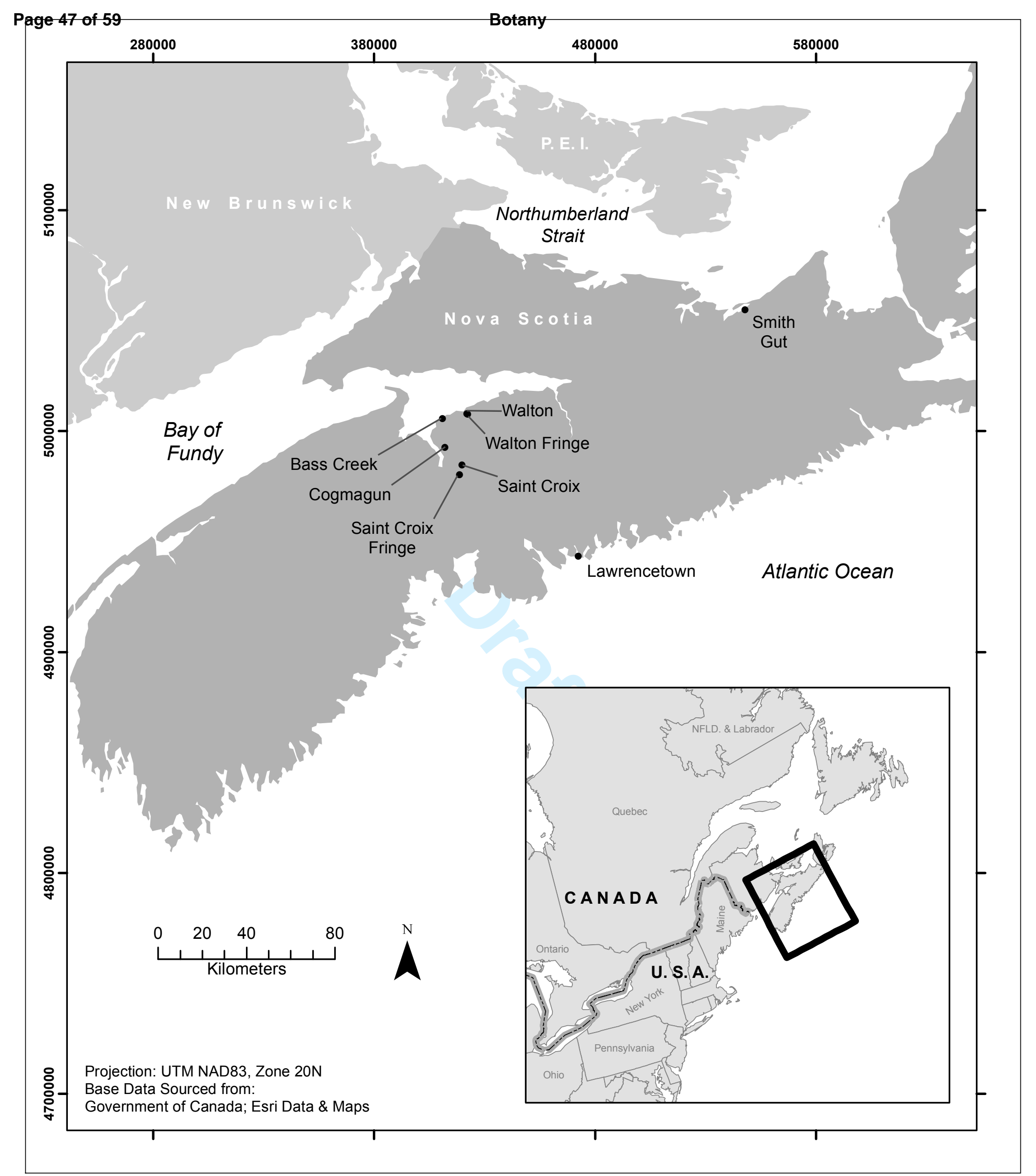



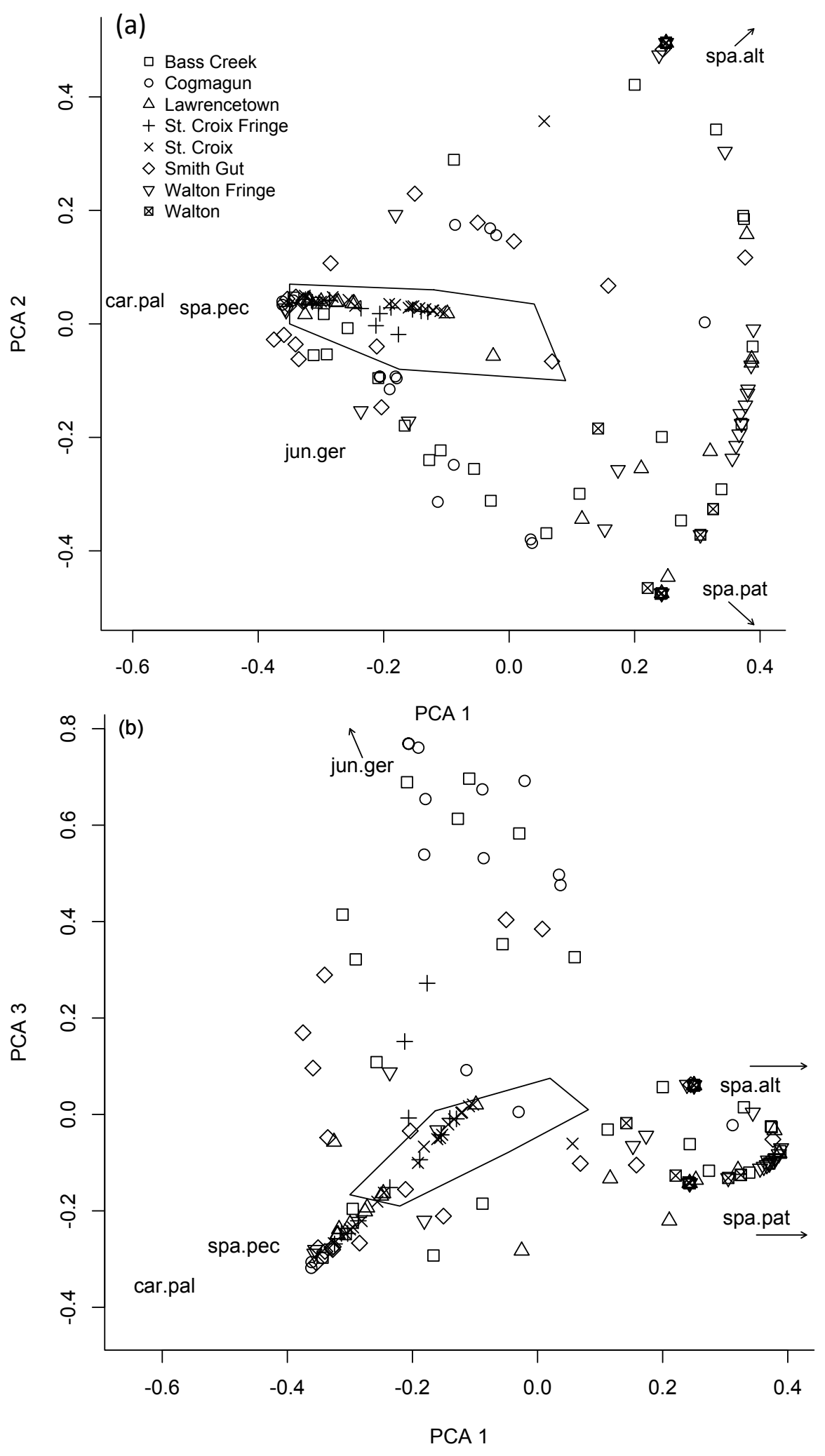

https://mc06.manuscriptcentral.com/botany-pubs 


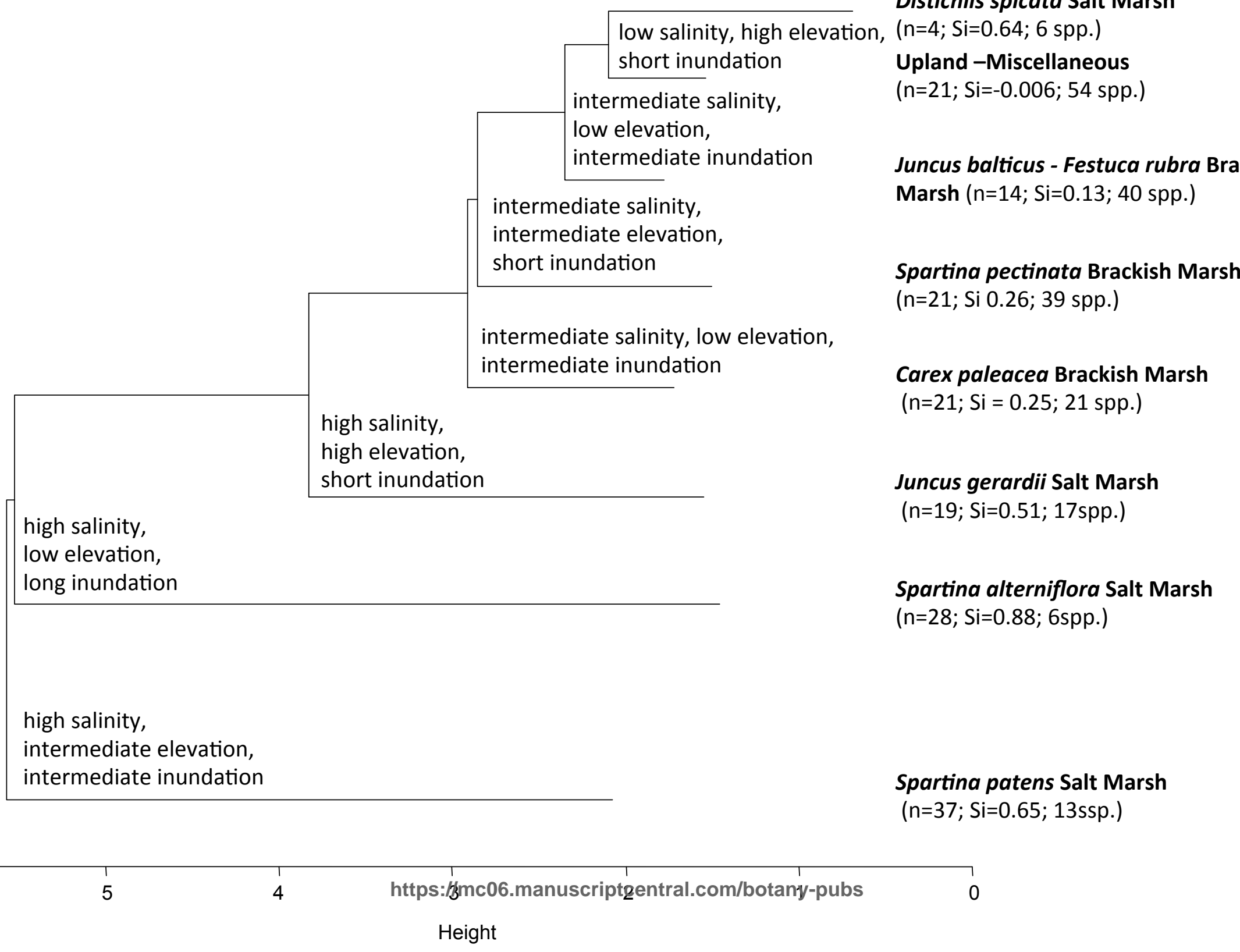



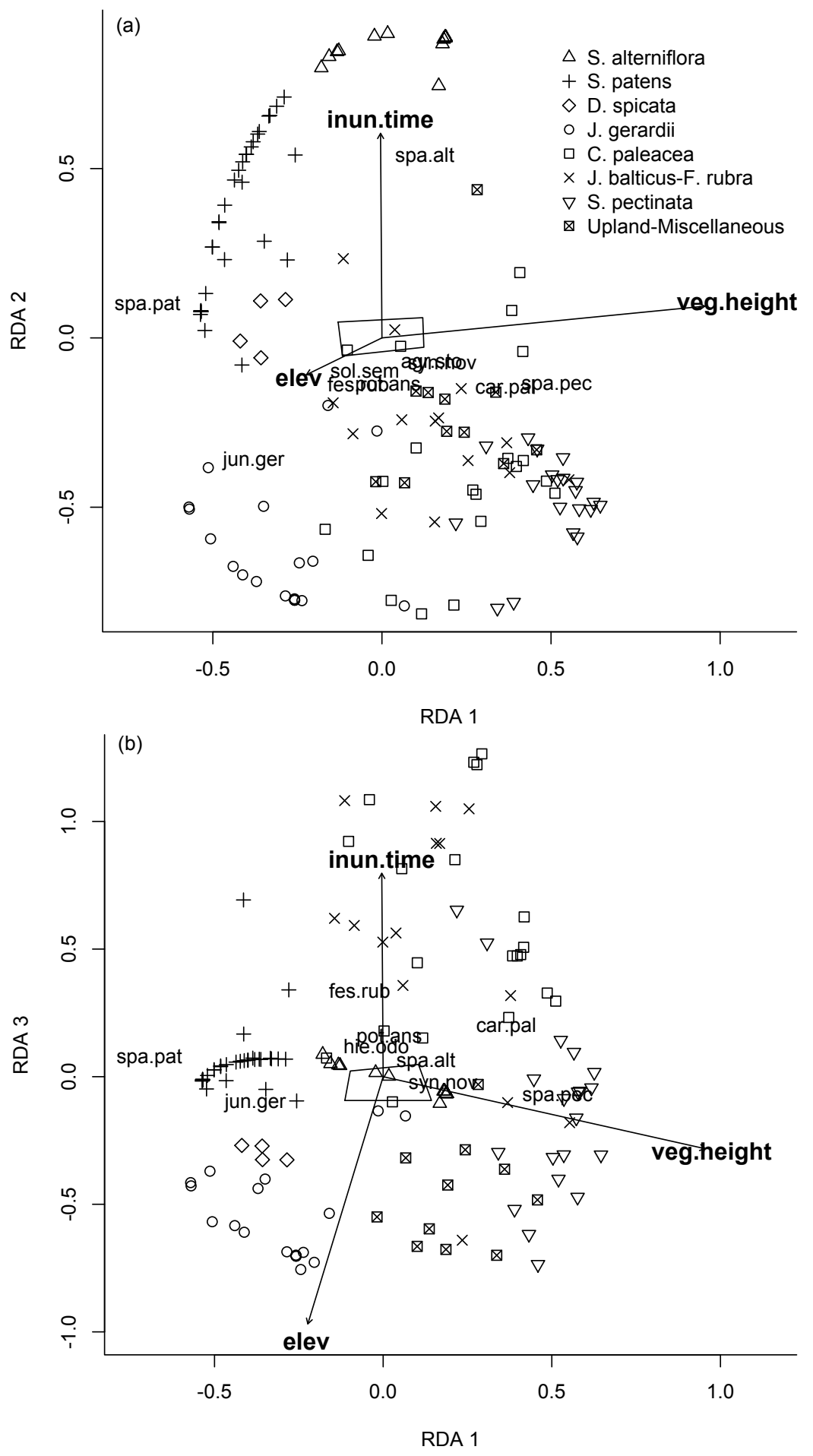

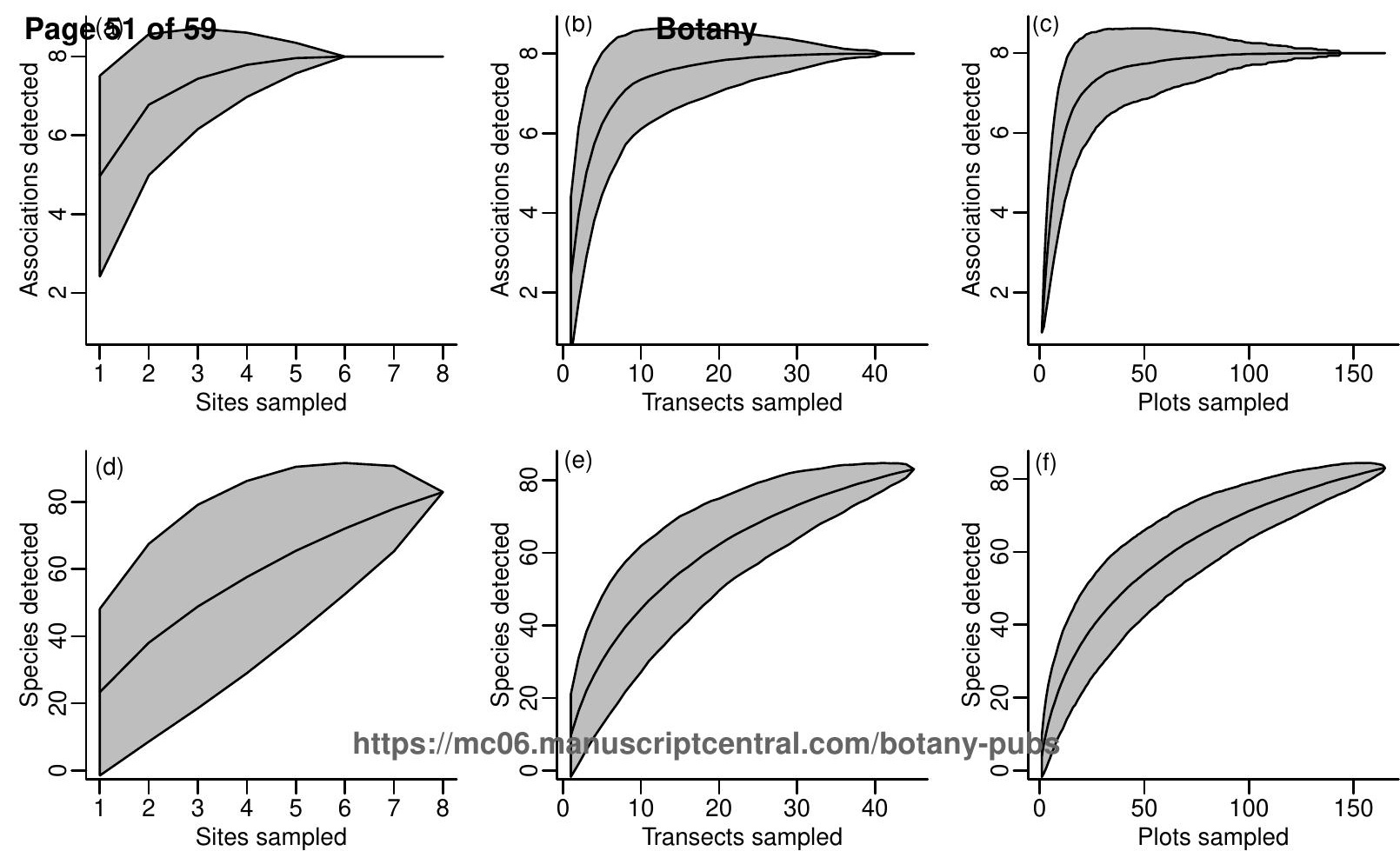


\section{Appendix A1. Detailed climate and site descriptions.}

Climate along the Atlantic coast is characterized by a long cool growing season and a winter that is more moderate in comparison with other parts of Nova Scotia. July temperatures are typically below $15^{\circ} \mathrm{C}$, and January temperatures are on average above $-5^{\circ} \mathrm{C}$. Precipitation is on average $1200 \mathrm{~mm}-1400 \mathrm{~mm}$ annually, except $1400 \mathrm{~mm}-1600 \mathrm{~mm}$ in northern Halifax County. The Bay of Fundy is similar climatically. The Bay of Fundy region receives shelter from the North Mountain and Cobequid hills. The Atlantic coast is comparatively cooler in summer in comparison with the Bay of Fundy, and also frequently exposed to high winds. On the Northumberland Strait, annual precipitation averages less than $1000 \mathrm{~mm}$. Mean July temperatures are $17^{\circ} \mathrm{C}$, and $<6^{\circ} \mathrm{C}$ in January. Fog is common on the Atlantic Coast in the summer and fall, the summer in the Bay of Fundy and early spring on the Northumberland coast (Davis and Browne 1996). Salt marshes in all of these areas experience ice and snow for a minimum of four months of the year (Bowron et al. 2012).

The Bay of Fundy Region is a macro-tidal embayment with semi-diurnal (twice daily) tides ranging from $3 \mathrm{~m}$ at the mouth of the Bay to a maximum of $16.3 \mathrm{~m}$ at the head (Desplanque and Mossman 2004). It is characterized by high suspended sediment concentrations, causing high rates of sediment deposition in intertidal environments (Chmura et al. 2001, Bowron et al. 2012). In the Atlantic Coastal Region, coastal wetlands experience micro-tidal conditions $(0.2-2.1 \mathrm{~m})$ twice daily, and are subject to higher wave energy (Bowron et al. 2012) due to ocean swells (Davis and Browne 1996). Tidal range within the Northumberland Strait varies from $0.3 \mathrm{~m}$ to $2.4 \mathrm{~m}$ (Davies 2012) from west to east, although mean water levels and tidal constituents are variable due to the presence of an amphidromic point on the eastern boundary of the Strait (Davidson-Arnott 2010). This results in diurnal tides at the western entrance of the 
Strait changing to larger semi-diurnal tides to the east along the NS shore (Desplanque and Mossman, 2004).

Relatively intact and regionally representative sites were selected. Current anthropogenic disturbance is largely absent from all of the study sites, which occur within a mixed forested, residential and agricultural context. Most of the sites are associated with transportation infrastructure (e.g., the upland edge of the Lawrencetown site is adjacent to a roadway), representing a vector for exotic species and limiting future landward migration in response to rising sea levels. Although the transportation infrastructure may influence hydrology and species composition, tidal flow and sediment input are unrestricted at all of these sites. In contrast with many New England marshes, a large portion of tidal wetlands in the Bay of Fundy are, or had historically been, dyked for agriculture (Ganong 1903). Remnant dykes are present at the St. Croix Fringe Marsh and also the Walton Fringe marsh. Although only the marshland outside of these dykes was sampled, agricultural activities including hay production would likely have taken place here as recently as 1900. At Cogmagun, historical agricultural use is evident by the presence of ditches that have been assimilated into a hybrid tidal creek network system. Previous studies in nearby regions have found that these historic agricultural disturbances are reflected in the vegetation communities (e.g., Jacobson and Jacobson 1989, Millard et al. 2013). While it could be argued that these study sites do not represent a pristine condition, the absence of current disturbance and the time elapsed since agriculture use is typical of this region, and therefore suitable as reference sites for restoration efforts.

\section{Additional References:}


Chmura, G., Coffey, A., and Crago, R. 2001. Variation in surface sediment deposition on salt marshes on the Bay of Fundy. J. Coast. Res. 17(1):221-227.

Davidson-Arnott, R. 2010. Introduction to Coastal Processes and Geomorphology. Cambridge University Press, Cambridge, UK.

Davies, M. 2012. Geomorphic Shoreline Classification of Prince Edward Island. [online]. Available from http://atlanticadaptation.ca/node/271 [accessed 8 January 2014].

Davis, D. S., and Browne, S. 1996. The Natural History of Nova Scotia: Topics and Habitats. Nova Scotia Museum of Natural History and Nimbus Press, Halifax.

Desplanque, C., and Mossman, D.J. 2004. Tides and their seminal impact on the geology, geography, history, and socio-economics of the Bay of Fundy, eastern Canada. Atlantic geol. 40 (1):1-130. doi: $10.4138 / 729$

Millard, K., Redden, A.M., Webster, T., and Stewart, H. 2013. Use of GIS and high resolution LiDAR in salt marsh restoration site suitability assessments in the upper Bay of Fundy, Canada. Wetl. Ecol. Manag. 21(4): 243-262. doi: 10.1007/s11273-013-9303-9. 
Appendix A2. Detailed descriptions of vegetation associations.

The $\boldsymbol{S}$. alterniflora Salt Marsh association was found in 28 plots across seven sites $(\mathrm{Si}=0.88)$. The silhouette index $(\mathrm{Si})$ is a measure of how distinct an association is, such that the closer $\mathrm{Si}$ is to 1 , the more similar plots within the group are to one another, and the stronger the fit as a cluster. Weakly positive Si scores indicate elements in common with other associations and negative Si scores indicate a poorly clustered group.

This association's namesake $S$. alterniflora was found in every plot with high mean abundance (cover: $93.9 \% \pm 22 \%$ ). S. patens was found in fewer plots; with relatively lower abundance ( cover: $29.3 \% \pm 16.7 \%$ ). No other species was found in more than three plots or $10.7 \%$ of sample plots in this association which is characterized by low species richness in general: six species total (mean: $1.5 \mathrm{species} / \mathrm{m}^{2}$ ). This association was found across all study sites except St. Croix fringe, and only one plot belonging to the association was found at St. Croix, and only two plots were found at Smith Gut. The indicator species $S$. alterniflora and sample plots in the association occur in areas with low elevation and with high inundation time (Figure 4a,b), intermediate salinity (Supplementary Figure S2)(although the average salinity across all plots in the association is quite high (Table 3), sediment of low organic content, small size and high bulk density (Fig. 4, Supplementary Figure S2). This association had the longest inundation times (Table 3). In terms of sediment, particle size was much lower than average and third smallest in comparison with other associations. Bulk density of sediment was greatest in comparison with other groups. Organic matter content of sediment were the lowest in comparison with other associations.

The $\boldsymbol{S}$. patens Salt Marsh association was found at 37 plots across five sites $(\mathrm{Si}=0.65)$, with high abundance of the dominant $S$. patens present in every sample plot $(92.1 \% \pm 24.1 \%$ cover). S. alterniflora was identified in $26 / 37$ sample plots with a mean of $32 \% \pm 25.2 \%$ cover. $A$. glabriuscula was found within $9 / 37$ plots with a low mean cover of $6.3 \% \pm 8.4 \%$. No other species was found in greater than $4 / 37$ sample plots. This association also shares Limonium carolinium and Salicornia maritima in common with the C. paleacea association, but lacks Suaeda maritima that is present in that association. As well, the $S$. patens association is slightly more species-rich than the C. paleacea one, with 13 species in total (mean: 2.4 species $/ \mathrm{m}^{2}$ ). Plots in this association were found at five of eight study sites: Bass Creek, Lawrencetown, Walton, Walton-fringe and just one plot at Cogmagun. The indicator species S. patens and sample plots are most closely associated with relatively high inundation durations, high salinity, intermediate elevations and sediments of low bulk density, small particle size, low organic composition (Figure 4 Supplementary Figure S2; Table 3). Mean pore water salinity of this association is high (Table 3).

Although the Distichlis spicata Salt Marsh association was only found in four plots across three sites, it is a distinct association $(\mathrm{Si}=0.64)$ characterized by high abundance of $D$. spicata $(95 \% \pm 5 \%$ cover). $S$. patens was also found within every plot, with lower mean abundance $(70 \% \pm 24.1 \%$ cover). S. alterniflora was found within three plots where its abundance comprised $68.3 \% \pm 2.2 \%$ cover. Three other species were identified within one sample plot only, for a total of 6 species belonging to this association (mean: $3.5 \mathrm{species} / \mathrm{m}^{2}$ ). Two sample plots were found at the Walton reference site, one at Walton Fringe and one at Bass Creek. The indicator D. spicata 
and the four sample plots are associated with relatively high elevation, low inundation time, high salinity and bulk density of sediment (Table 3). Salinity/sediment characteristics are based on measurements from one plot only but this plot had very high salinity, comparable to that in the $J$. gerardii association (Table 3 ).

The J. gerardii Salt Marsh association was found in 19 plots at two sites ( $\mathrm{Si}=0.51)$. The main species $J$. gerardii was present in all plots at high abundance (cover: $94.1 \% \pm 9.8 \%$ ). $S$. patens was found in about half of plots (9/19 plots) with variable abundance (mean of $36.5 \% \pm 32.9 \%$ cover. S. sempervirens and Atriplex glabriuscula were each found in 6/19 sample plots with mean covers of $36.7 \% \pm 30.1 \%$ and $1.5 \% \pm 2 \%$ respectively. No other species were found within more than three sample plots. Plantago major and S. pectinata occurred in relatively high abundance within the single sample plots where they were found. Total richness of the association was 17 species (mean: 3.05 species $/ \mathrm{m}^{2}$ ). This association was found only at Bass Creek and Cogmagun study sites, and although Smith Gut had relatively high abundances of $J$. gerardii (Fig. 2), none of the plots at that site were classified to this type. The indicator species $J$. gerardii and the majority of sample plots in this association tend to occur in areas with high salinity, high elevation, and short inundation times (Supplementary Figure S2). Mean elevation is second greatest of the associations and inundation time is the lowest (Table 3). Sediment characteristics are intermediate for most variables, and pore water salinity was the highest measured (Table 3).

The Carex paleacea Brackish Marsh association was assigned to 21 plots across seven sites ( $\mathrm{Si}=0.25)$ (Figure 3; Table 3), and is characterized by dominance of C. paleacea, which was present in every plot and of greatest abundance (mean cover \pm standard deviation: $97 \% \pm 6.6 \%$ ) within the association. 21 species were identified within this group (mean plot richness: 4.5 species/ $\mathrm{m}^{2}$ ). In addition to the dominant sedge, several other species occurred with notable abundance and frequency. Agrostis stolonifera was identified within almost half of sample plots (10), with a mean abundance of $16.2 \% \pm 3.3 \%$. Festuca rubra was found in eight/21 plots with a mean abundance of $6.3 \% \pm 9.95 \%$. S. patens, J. gerardii and Argentina anserina were found within $7 / 21$ sample plots with mean abundances of $5.14 \% \pm 3.5 \%, 4.29 \% \pm 3.7 \%$, and $1.4 \% \pm$ $1.4 \%$ respectively. S. alterniflora and S. semprevirens were the only other species found in more than five sample plots. They each had small mean abundances: $2.6 \% \pm 1.8 \%$, and $1.9 \% \pm 1.6 \%$ respectively. The indicator species C. paleacea and the majority of sample plots in this community are associated with higher inundation time and greater sediment size (Supplementary Figure S2). Mean pore water salinity was intermediate and indicative of brackish conditions (Table 4). Sediments were slightly larger than average in particle size, low in bulk density and had the highest organic matter content (Table 3).

The $\boldsymbol{J}$. balticus - F. rubra Brackish Marsh association was found in 14 plots across seven sites $(\mathrm{Si}=0.13)$, and is one of the most species rich, with 40 species identified in total (mean: 7.7 species $/ \mathrm{m}^{2}$ ). Six indicator species characterize this association (Table 3 ). The strongest indicator species is $J$. balticus (Table 3): 10 of 14 plots containing this species belong to this association and it is represented in relatively high abundance where found: $90.4 \% \pm 13.4 \%$ cover. F. rubra is next strongest indicator and the most frequent species, present in all but two sample plots this association (12/14 plots). F. rubra occurred in high abundance: $90.3 \%$ cover $\pm 23.7 \%$. 
Though not an indicator species, C. paleacea was identified in more than half (9) of sample plots, where it had relatively high cover values: $42 \% \pm 27 \%$. No other species were found in greater than six plots in the association, but several species were exclusive to the J. balticus-F. rubra association and represent indicator species (Table 3). Hierochloe odorata was relatively uncommon throughout the study (16 sample plots with $41 \% \pm 27.5 \%$ cover), but was found in six sample plots belonging to this association, expressed in higher abundance than elsewhere outside the association: cover $=64.7 \% \pm 13.2 \%$. Scutellaria galericulata was found five times throughout this study, with four occurrences belonging to the J. balticus-F. rubra association (cover = $27.1 \% \pm 30.5 \%$ ). Myrica gale was found only within two sample plots; both belong to this association (cover $=22 \% \pm 25.4 \%$ ). Carex hormathodes was found within only three sample plots throughout the study, two of which belong to this association (cover $=6.1 \% \pm 8.3 \%$ ). Both indicator species $J$. balticus and F. rubra and sample plots in the association tend to occur in areas with large particle size, high organic matter, high inundation time, low elevation and relatively low salinity (Figure 4; Supplementary Figure S2; Table 3).

The S. pectinata Brackish Marsh association was found at 21 plots across seven sites $(\mathrm{Si}=0.26)$. The dominant $\mathrm{S}$. pectinata was present in every plot with mean of $91 \% \pm 10.7 \%$ cover. C. paleacea was the second most frequent species, present within most (12/21 or $80.9 \%)$ sample plots at $44.5 \% \pm 32.7 \%$ cover. $S$. novi-belgii, A. stolonifera, and $S$. sempervirens were found in eight, seven and six plots respectively, comprising $11.9 \% \pm 24.2 \%, 13.4 \% \pm 37.2 \%$, and $46.7 \% \pm 10.3 \%$ cover respectively. Total species richness of this association is 39 species (mean: $6.1 \mathrm{species} / \mathrm{m}^{2}$ ). S. pectinata and plots classified into this association were found in areas with relatively high elevation, intermediate to low salinity and low inundation duration (Table 3; Figure 4; Supplementary Figure S2). Sediment particle size was relatively high on average, but also had great variability (Table 3 ).

The remaining 21 plots could not be classified and form a "miscellaneous" group ( $\mathrm{Si}=-$ 0.006). All of these plots were found at the St. Croix-reference and St. Croix-fringe sites. This group contained the highest number of misclassifications: seven plots, representing $33 \%$ of plots within the group. Other plots maintained weakly positive Si scores. Total species richness is 54 species, larger than any other association (mean: $7.3 \mathrm{species} / \mathrm{m}^{2}$ ). The strongest indicator species of this group of plots is Taraxacum officinale; a non-native, weedy upland species found in 8/21 plots with abundance of $13.5 \% \pm 14 \%$ cover. Galium palustre was the most abundant species of the group, found in $9 / 21$ plots with a mean abundance of $46.2 \% \pm 32.5 \%$ cover and represents the second strongest indicator value. All other indicator species were uncommon throughout this study or entirely exclusive to the upland/miscellaneous plots. Seven of ten occurrences of Equisetum arvense within this study were found within this association. Four of five study occurrences of Poa pratensis occur within this association. Seven of eight occurrences of Solidago canadensis belong to this association. Two of three occurrences of Bromus inermis were found within this association. All four occurrences of Solidago gigantea and all three occurrences of Centauria nigra belong to this association. This group of indicator species form an assemblage of species absent from all other tidal wetland associations identified. Plots and indicator species are associated with high elevation, low salinity and low inundation time (Figures 3,4 Supplementary Figure S2; Table 3). 
Upland and Miscellaneous: Cluster analyses show 21 sample plots do not significantly fit into the classification hierarchy. Indicator species analysis reveals these plots are largely characterized by presence of upland, freshwater wetland associated and exotic forbs and graminoids. The weakly negative Si score suggests that these plots share floristic similarities with other associations. Some of the miscellaneous sample plots represent transition with the upland edge of the marsh. It may also be the case that a few of these sample plots represent distinctive community types that were underrepresented on the eight study sites surveyed.

Forb dominated communities, such as those panne areas described in Northern New England (eg., Ewanchuk and Bertness 2004), or alluded to by other studies in Nova Scotia (eg., Thannheiser 1984) were not a conspicuous feature of the marshes sampled for this study. The authors did however observe shallow pools of permanent standing water on the marshes that in some cases supported living aquatic vegetation. Numerical classification did not reveal a statistically significant plant association here. This may be due to their limited representation and therefore small sample size. Of three sample plots that contained open standing water, one contained the species Ruppia maritima L. (Sea Ditchgrass) and was numerically allocated to the miscellaneous grouping of plots. Two additional sample plots were collected from pools that contained no vegetation but were fringed by the Spartina alterniflora and Carex paleacea associations. Other studies in the region also identify shallow water pools colonized by the submergent aquatic Ruppia maritima or that are fringed by dominant graminoids found in this study, especially Spartina alterniflora (Bleakney et al. 1979, Patriquin 1981, Chmura et al. 1997, Millard et al. 2013). Shallow pools of standing water contribute to overall marsh biodiversity, and are worthy of mention because they are more common on northern marshes (Noel and Chmura 2011) and because their habitat value is well recognized (Bleakney et al 1979, Roberts and Robertson 1986). 